\title{
Fluoride Concentration in Community Water and Bottled Drinking Water : A Dilemma Today
}

\author{
Dhingra $S,{ }^{1}$ Marya $\mathrm{CM},{ }^{2}$ Jnaneswar $A,{ }^{3}$ Kumar $\mathrm{H}^{4}$
}

\author{
${ }^{1}$ Department of Public Health Dentistry \\ SGT Dental College, Hospital and Research Institute \\ Budhera, Gurgaon (Haryana) India \\ ${ }^{2}$ Department of Public Health Dentistry \\ Sudha Rustagi College of Dental Sciences and \\ Research, Faridabad (Haryana), India \\ ${ }^{3}$ Department of Public Health Dentistry \\ Kalinga Institute of Dental Sciences, Bhubaneswar \\ (Odisha), India \\ ${ }^{4}$ Department of Oral Pathology \\ SGT Dental College, Hospital and Research Institute, \\ Budhera, Gurgaon (Haryana), India
}

\section{Corresponding Author}

Sonal Dhingra

Department of Public Health Dentistry

SGT Dental College, Hospital and Research Institute

Budhera, Gurgaon (Haryana), India

Email: sonal.673@gmail.com

\section{Citation}

Dhingra S, Marya CM, Jnaneswar A, Kumar H. Fluoride Concentration in Community Water and Bottled Drinking Water : A Dilemma Today. Kathmandu Univ Med J 2013;42(2):117-120.

\begin{abstract}
Background

Because of the potential for contamination of municipal water supplies, people appear to be turning to alternative sources for their pure drinking water.

\section{Objectives}

The present study analyzed the fluoride concentration in community water and bottled drinking water sold in Faridabad city.

\section{Methods}

A comparative evaluation of fluoride content in community water supply and bottled drinking water was done using ion-selective electrode method. The community water samples were collected from six different areas (i.e. north zone, south zone, east zone, west zone and central zone) in the city from public health water supply taps while bottled drinking water samples were randomly picked from grocery shops or supermarkets.
\end{abstract}

\section{Results}

The fluoride concentration in the community water supply in this study ranges from 0.11 to $0.26 \mathrm{mg} / \mathrm{L}$ with mean fluoride concentration of $0.17 \mathrm{mg} / \mathrm{L}$. The mean concentration of fluoride in bottled drinking water was $0.06 \mathrm{mg} / \mathrm{L}$. The differences observed between mean of two water samples was statistically significant.

\section{Conclusion}

The results obtained from the present study clearly state that the fluoride concentration was insufficient in community water supply from all the areas and also was deficient in bottled drinking water sold in Faridabad city. So, Alternative sources of fluorides should be supplemented for optimal dental benefits from the use of fluoride.

\section{KEY WORDS}

Bottled water, drinking water, fluoride

\section{INTRODUCTION}

Water is one of the five sacred elements, which epitomize life. Contaminated water supplies may cause health risk. Because of the potential for contamination of municipal water supplies, people have resorted to alternative sources for their pure drinking water. Bottled (packaged) water is widely consumed now-a-days, since it is pure, has better taste and confers higher social status on consumer. ${ }^{1}$
Fluorides have been recognized as an effective means for the prevention of dental caries. Though fluoride enters the body through food, water, industrial exposure, drugs, cosmetics, etc., drinking water is the major contributor (75-90\% of daily intake). ${ }^{2}$ The problem of excessive fluoride in groundwater in India was first reported in 1937 in the State of Andhra Pradesh. ${ }^{3}$ In India, because of consumption of water with high fluoride concentration, approximately 
62 million people including six million children suffer from fluorosis. ${ }^{4}$ Seventeen states in India have been identified as endemic for fluorosis and Haryana is one of them.

The permissible limit as given by Bureau of Indian Standards (BIS) and World Health Organization (WHO) is 0.6-1.2 mg/l and $1.5 \mathrm{mg} / \mathrm{l}$ respectively for fluoride in drinking water. ${ }^{5,6}$

International studies supports the widely held view that the majority of bottled waters available contain negligible fluoride in terms of its dental health benefits. ${ }^{7-14}$

From the available literature it was found that the data regarding fluoride concentration in community water and bottled drinking water sold in Faridabad city is lacking. With the assumption that the bottled water is being widely used nowadays, this study was undertaken in order to fill this lacuna. The present study analyzed the fluoride concentration in community water and bottled drinking water sold in Faridabad city.

\section{METHODS}

A comparative evaluation of fluoride content in community water supply and bottled drinking water sold in Faridabad city, Haryana was done using ion-selective electrode method.

Ethical clearance was taken from the ethical review board of Sudha Rustagi College of Dental Sciences and Research, Faridabad (Haryana), India.

\section{Source of water and Sampling}

Community water supply: The water samples were collected from six different areas (i.e. one from north zone, one from south zone, one from east zone, one from west zone and two from central zone) in the city from public health water supply taps. The main source of water at household level comprised of public health water supply only. This was ascertained through a prior survey in the city. The detailed parameters like dietary pattern, amount of water consumed daily per individual were assumed to be similar among all the natives.

Bottled drinking water: Randomly selected nine different brands (out of 17 brands being sold in the market) of bottled water sold in Faridabad were collected from supermarkets, grocery stores, and health shops.

\section{Sample analysis}

All the water samples (one litre each) were collected by the chief investigators as triplicate and were collected in precleaned sterilized hard plastic bottles and stored at room temperature. The water samples were sent for analysis on the same day of water collection. The samples of water were pre-coded and not disclosed to the technician so as to eliminate any potential bias.

In the laboratory, samples of water were stored at room temperature $\left(17-25^{\circ} \mathrm{C}\right)$ prior to analysis. The fluoride concentration of each water sample was analysed three times to assess the reliability of the method. The fluoride estimation was done using ion-selective electrode method.

SPSS (Statistical Package for Social Sciences) Version 19 was used to determine the mean and standard deviation of fluoride in water samples. Mann Whitney test was used to compare the fluoride concentration of community water supply and bottled drinking water at $5 \%$ level of significance.

\section{RESULTS}

The findings of the present investigation are summarized in tables 1 and 2 . The results obtained for mean fluoride concentration (in $\mathrm{mg} / \mathrm{L}$ ) of community water supply and bottled drinking water sold in Faridabad is shown in table 1.

Table 1. Mean Fluoride concentration in community water supply and bottled drinking water.

\begin{tabular}{|c|c|}
\hline Sample of water & Mean Fluoride concentration $(\mathrm{mg} / \mathrm{L})$ \\
\hline SW1 & 0.15 \\
\hline SW2 & 0.13 \\
\hline SW3 & 0.11 \\
\hline SW4 & 0.26 \\
\hline SW5 & 0.16 \\
\hline SW6 & 0.18 \\
\hline SW7 & 0.1 \\
\hline SW8 & 0.12 \\
\hline SW9 & NIL \\
\hline SW10 & 0.1 \\
\hline SW11 & NIL \\
\hline SW12 & 0.06 \\
\hline SW13 & 0.12 \\
\hline SW14 & NIL \\
\hline SW15 & 0.03 \\
\hline
\end{tabular}

* Out of 15 samples of water; sample SW1 to SW6 are the community water supply samples while SW7 to SW15 are the bottled drinking water samples.

Table 2. Mean and Standard Deviation of fluoride concentration in community water supply and bottled drinking water.

\begin{tabular}{ll} 
Sample of water & $\begin{array}{l}\text { Fluoride concentration (mean } \pm \\
\text { standard deviation) }\end{array}$ \\
\hline Community water supply $(n=6)$ & $0.17 \pm 0.05$ \\
\hline Bottled drinking water $(n=9)$ & $0.06 \pm 0.05$ \\
*Mann Whitney test; $\mathrm{p}=0.003$ &
\end{tabular}

Out of 15 samples of water; sample SW1 to SW6 are the community water supply samples while SW7 to SW15 are the bottled drinking water samples.

The fluoride concentration in the community water supply varied from minimum of 0.11 to a maximum of $0.26 \mathrm{mg} / \mathrm{L}$ with mean fluoride concentration of $0.17 \mathrm{mg} / \mathrm{L}$. Out of nine 
samples collected for the bottled drinking water, fluoride was not found in three samples while other samples present a concentration ranging from 0.03 to $0.12 \mathrm{mg} / \mathrm{L}$. The mean concentration of fluoride in bottled drinking water was $0.06 \mathrm{mg} / \mathrm{L}$.

The grand mean and the standard deviation of the samples for both community water supply and bottled drinking water is shown in table 2 .

The differences observed between mean of two water samples was statistically significant.

\section{DISCUSSION}

Excessive consumption of fluoride above the optimal level causes dental and skeletal fluorosis. ${ }^{15,16}$ Studies done by Armfield et.al clearly showed that the consumption of non-fluoridated community and bottled water may put the children at the increased risk of developing caries. ${ }^{17-19}$ So, the importance of consumption of fluoride in optimal amount is very essential for a better dental health. Hence, the determination of fluoride ion in water is important for determining the dosage of fluoride supplements or necessity of topical fluoride in the patients.

The fluoride concentration in the community water supply in this study ranges from 0.11 to $0.26 \mathrm{mg} / \mathrm{L}$ with mean fluoride concentration of $0.17 \mathrm{mg} / \mathrm{L}$. This result was in agreement with the previous studies conducted by Lalumandier JA et al. ${ }^{7,20}$ According to the water quality standards for drinking water in India (IS 10500:1991), the maximum permissible limit of fluoride in drinking water is $1.2 \mathrm{mg} / \mathrm{L}$. In the light of the result obtained, the fluoride levels of the community water supply were in the range of permissible limit for fluoride in drinking water. ${ }^{21}$

The fluoride concentration in the bottled drinking water had mean value of $0.06 \mathrm{mg} / \mathrm{L}$ which is in agreement with the findings of Lalumandier JA et al. ${ }^{7,22,23}$ The maximum limit of fluoride was estimated to be $0.12 \mathrm{mg} / \mathrm{L}$ which was in accordance with the standard for the packaged drinking water as recommended by the IS 14543: $2004 .{ }^{24,25}$

In the present study, four out of nine different brands of bottled drinking water specified the presence of fluoride on the label, thus it may be inferred that there has been a laxity towards regularizing the labels on the part of water bottle industries.

The study findings can be generalized to the Faridabad city since it assessed the water samples from all the zones of Faridabad and also the bottled drinking water was collected owing to the ones frequently used in the Faridabad city.

Though Haryana is said to be endemic for fluorosis, yet it is moderately affected (30\%-40\% area is only affected). This fact substantiates the low levels of fluoride in community drinking water in the Faridabad city; it remains unaffected by the dental fluorosis. Hence, various alternatives for topical as well as systemic fluorides should be suggested for the population in this city in order to have better dental health.

Bottled drinking water on the other hand are packaged in accordance with the standard for the packaged drinking water as recommended, since it is supplied to all the parts of country. So, as more and more people are resorting to bottled drinking water, they need to be informed about its mineral content so that they can opt for appropriate supplemental measures to fulfill this laxity.

The present study was limited in some aspects :

- The dietary pattern of the population was not assessed for fluoride content.

- The amount of water consumed daily was not taken in consideration.

- Other forms of topical fluoride used as dentifrices or mouthrinses was not assessed.

However, these limitation did not alter the study results as the present study aimed only to assess and compare the fluoride levels in both community drinking water and bottled drinking water.

\section{CONCLUSION}

The results obtained from the present study clearly state that the fluoride concentration was insufficient in both community water supply and bottled drinking water sold in Faridabad city.

Hence, people should make better choices which should supplement their health as well. The information gathered from this study will support important research on the public health and dental health.

\section{REFERENCES}

1. Babaji I, Shashikiran NN, Reddy S. Comparative evaluation of trace elements and residual bacterial content of different brands of bottled waters. J Indian Sot Pedo Prev Dent 2004 December; 22 (4): 201-204.

2. Sarala K, Rao PR. Endemic fluorosis in the village Ralla Anantapuram in Andhra Pradesh: An epidemiological study. Fluoride 1993; 26: 177180.

3. Short HE, McRobert GR, Bernard TW, Mannadinayar AS. Endemic fluorosis in the Madras Presidency. Ind J Med Res 1937; 25: 553-561.

4. Susheela AK. Fluorosis management programme in India. Curr Sci 1999; 77(10): 1250-1256.

5. Bureau of Indian Standards. Indian Standard Drinking Water Specifications. 1983 IS:10500, New Delhi.

6. World Health Organization. Guidelines for drinking water quality, Vol I. Recommendations (1984). Geneva (Switzerland): WHO.

7. Lalumandier JA, Ayers LW. Fluoride and bacterial content of bottled water vs tap water. Arch Fam Med 2000; 9: 246-250.

8. Tate WH, Chan JT. Fluoride concentrations in bottled and filtered waters. Gen Dent 1994; 42: 362-366. 
9. Toumba KJ, Levy S, Curzon MEJ. The fluoride content of bottled drinking waters. Br Dent J 1994; 176: 266-268.

10. Weinberger SJ. Bottled drinking waters: are the fluoride concentrations shown on the labels accurate? Int J Paediatr Dent 1991; 1: 143-146.

11. Zohouri FV, Maguire A, Moynihan PJ. Fluoride content of still bottled waters available in the North-East of England, UK. Br Dent J 2003; 195: 515-518.

12. Ahiropoulos V. Fluoride content of bottled waters available in Northern Greece. Int J Paediatr Dent 2006; 16: 111-116.

13. Jimenez-Farfan MD, Hernandez-Guerrero JC, Loyola-Rodriguez JP, Ledesma-Montes C. Fluoride content in bottled waters, juices and carbonated soft drinks in Mexico City, Mexico. Int J Paediatr Dent 2004; 14: 260-266.

14. Thippeswamy H M, Kumar N, Anand S R, Prashant G M, Chandu G $N$. Fluoride content in bottled drinking waters, carbonated soft drinks and fruit juices in Davangere city, India. Indian J Dent Res 2010;21:528-30.

15. Marya CM, Ashokkumar BR, Dhingra S, Dahiya V, Gupta A. Exposure to High-Fluoride Drinking Water and Risk of Dental Caries and Dental Fluorosis in Haryana, India. Asia Pac J Public Health 2012 Oct 15.

16. Charu Mohan Marya, BR Ashokkumar, Vandana Dahiya, Anil Gupta. Prevalence and Severity of Dental Fluorosis in Endemic Fluoride Areas of Haryana, India: An Epidemiologic Study. Acta Stomatol Croat 2010; 44(3):152-158.
17. Armfield JM, Spencer AJ. Comparison of non public water: implication for children's caries experience. Community Dent Oral Epidemiol 2004; 32: 283-296.

18. Riodon PJ. Dental caries and fluoride exposure in Western Australia. $J$ Dent Res 1991; 70: 1029-1034.

19. Marya CM, Dhingra S, Marya V, Ashokkumar BR. Relationship of dental caries at different concentrations of fluoride in endemic areas: an epidemiological study. J Clin Pediatr Dent 2010 Fall;35(1):41-5.

20. Khan AA, Whelton $H$, O'Mullane D. Determining the optimal concentration of fluoride in drinking water in Pakistan. Community Dent Oral Epidemiol 2004; 32: 166-172.

21. IS 10500: 1991. Indian standard drinking water- specification (First Revision Online). [Accessed on May 5, 2013]. Available from: http:// www.bis.org.in/bis/html/10500.html.

22. DaCosta GRH, Moura PG, Pessan JP, Ramires I, Costa B. Fluoride concentration in bottled water on the market in the municipality of Sao Paulo. Rev Saude Publica 2008; 42(1): 1-4.

23. Ramires I, DaCosta GRH, Cattan L, Gomes P, Lauris JRP, Buzalaf MAR. Evaluation of the fluoride concentration and consumption of mineral water. Rev Saude Publica 2004; 38(3): 1-7.

24. IS 14543:2004. Packaged drinking water (other than Packaged natural water)- Specification [online]. [Accessed on May 5, 2013]. Available from: http://www.bis.org.in/bis/html/14543.html.

25. Bottle water industry in India. Site copyright (C2006. Available from: http://www.gits4u.com/water/water16.htm [last cited on 2013 May 5]. 